\title{
The infection of trematodes on rice frogs (Fejervarya cancrivora) in Karawang Regency, West Java
}

\author{
Gloria Animalesto ${ }^{1, *}$ \\ ${ }^{1}$ Zoology Division, Research Center for Biology, Indonesian Institute of Sciences (LIPI) Gedung Widyasatwaloka, J1. Raya Jakarta- \\ Bogor Km. 46, Cibinong, West Java, Indonesia 16911
}

\begin{abstract}
Fejervarya cancrivora is often used as raw material for food and export commodities. In 2014, it was recorded that Karawang Regency was the largest producer of frog's legs meat in West Java. Research on trematode worms of $F$. cancrivora from Karawang Regency was conducted to find out the diversity of trematodes worms and its infection patterns. The observation was carried out on 120 frogs. The lungs, stomach, intestine, and caecum were examined for trematodes. The results showed that the $F$. cancrivora infected by four species of trematodes i.e., Glypthelmins sp., Pleurogenoides sp., Haematoloechus sp., and Diplodiscus sp. with a prevalence of $25.8 \%, 18.3 \%, 35.8 \%$, and $23.3 \%$, respectively, and parasite index 1 $25,1-268,1-19$, and 1-23 individual parasite in each host, respectively.
\end{abstract}

\section{Introduction}

Trematodes of frog in Indonesia have been investigated only by a few authors [1-2]. They reported trematode infection to the genus level from anurans. The negative impact of trematode presence in frogs intensively reported on two different genera of trematodes, Ribeiroia and Echinostoma. Both of them use tadpoles serve as a second intermediate host and cause limb malformation and tadpole mortalities, respectively [3].

Fejervarya cancrivora has widespread distribution throughout Indonesia, especially in Java [4]. Indonesia dedicated as the largest exporters of frog's legs for consumption as food, and predominantly from $F$. cancrivora caught in natural habitat in Java Island [5]. In 2014, it was recorded that Karawang Regency was the largest producer of frog's leg meat in West Java [6]. For amphibians, trematode dominates in ranids, tree frogs, and aquatic amphibians [7]. Therefore, the current study aimed to find out the diversity of trematode in frog viscera and investigate its infection pattern.

\section{Material and Methods}

\subsection{Frog Collection}

A total of 120 frogs were collected by hand on $16^{\text {th }}-27^{\text {th }}$ May 2018 by Dra. Hellen Kurniati and her team in the ricefield of East Karawang Regency, Subdistrict of Klari Sukaresmi, Anggita village and Gintung village.

\subsection{Parasite Collection and Preservation}

The snout-vent length of all frogs was measured first. The lungs, stomach, intestine, and caecum were dissected and placed separately in a petri dish containing $70 \%$ alcohol. All organs were examined under a dissecting microscope. Any trematodes found were fixed in a vial containing $70 \%$ alcohol for morphology study.

\subsection{Trematode Staining}

Trematodes stained by acetocarmine for 5-10 minutes immersion, then continued with the destaining process. The worms were destained in ethyl acetate until the worms brighten (pinkish) and the organs are visible. After the destaining, the process of dehydration was applied gradually with graded alcohol as $70 \%, 80 \%$, $90 \%$, and $100 \%$, then cleared in methyl salicylate and mounted in Canada balsam.

\subsection{Trematode Identification}

The morphology of trematodes was observed under a microscope and identified according to Bray et al. [8] and relevant journals. Each kind of species was photographed and measured by a micrometer scale.

\subsection{Data Analysis}

Every individual of trematode species was counted to reveal the prevalence, mean intensity and mean abundance of trematode by Microsoft Excel 2013. The collected species were classified into genus level. The infection pattern based on host size and host sex were estimated using IBM SPSS Statistics 23.

\footnotetext{
* Corresponding author: glorianimalesto@gmail.com
} 


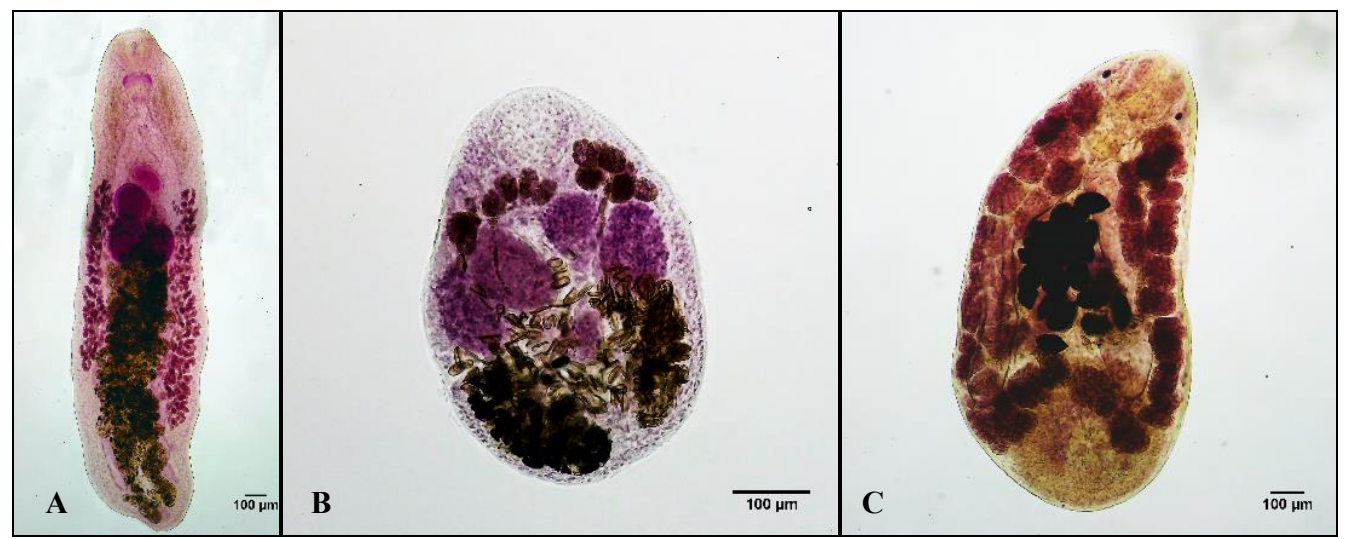

Fig. 1. A. Glypthelmins sp., B. Pleurogenoides sp., C. Diplodiscus sp.

Table 1. Summary of trematode infection in each site of viscera

\begin{tabular}{|c|c|c|c|c|c|c|c|c|c|}
\hline \multirow{3}{*}{ Trematode species } & \multicolumn{8}{|c|}{ Site of Infection } & \multirow{3}{*}{$\begin{array}{c}\text { Infection } \\
\text { rate } \\
\text { (Range) }\end{array}$} \\
\hline & \multicolumn{2}{|c|}{ Lungs } & \multicolumn{2}{|c|}{ Stomach } & \multicolumn{2}{|c|}{ Intestine } & \multicolumn{2}{|c|}{ Caecum } & \\
\hline & $\operatorname{Pr} \%$ & MI & $\operatorname{Pr} \%$ & MI & $\operatorname{Pr} \%$ & MI & $\operatorname{Pr} \%$ & MI & \\
\hline Haematoloechus sp. & 35.8 & 2.5 & - & - & - & - & - & - & $1-19$ \\
\hline Diplodiscus sp. & - & - & - & - & 6.7 & 3.1 & 19.2 & 4.6 & $1-23$ \\
\hline Pleurogenoides sp. & - & - & 1.7 & 1.5 & 17.5 & 48.4 & 0.8 & 1 & $1-268$ \\
\hline Glyphtelmins sp. & - & - & 1.7 & 3 & 25 & 4.3 & 1.7 & 1 & $1-25$ \\
\hline
\end{tabular}

$\mathrm{Pr} \%=$ Prevalensi, $\mathrm{MI}=$ Mean Intensity

Table 2. Number of parasitized host and prevalence (\%), mean intensity (MI), mean abundance (MA) number of trematode recovered and occupied microhabitat in the host

Helminth species $\quad \begin{aligned} & \text { Number of } \\ & \text { individuals } \\ & \text { parasitized } \\ & \text { (prevalence \%) }\end{aligned} \quad$ MI \pm SD $\quad$ MA \pm SD $\quad \begin{gathered}\text { Number } \\ \text { recovered }\end{gathered}$ Site of Infection

\begin{tabular}{cccccc}
\hline Haematoloechus sp. & $43(35.8 \%)$ & $2.5 \pm 2.3$ & $0.9 \pm 2.2$ & 109 & Lungs \\
\hline Diplodiscus sp. & $28(23.3 \%)$ & $4.7 \pm 4.2$ & $1.1 \pm 4.0$ & 131 & $\begin{array}{c}\text { Intestine } \\
\text { Caecum }\end{array}$ \\
\hline Pleurogenoides sp. & $22(18.3 \%)$ & $46.4 \pm 44.7$ & $8.5 \pm 39.0$ & 1021 & $\begin{array}{c}\text { Stomach } \\
\text { Intestine } \\
\text { Caecum }\end{array}$ \\
\hline Glyphtelmins sp. & $31(25.8 \%)$ & $4.3 \pm 4.4$ & $1.2 \pm 3.9$ & 138 & $\begin{array}{l}\text { Stomach } \\
\text { Intestine } \\
\text { Caecum }\end{array}$ \\
\hline
\end{tabular}

Table 3. Correlation between total infection of each trematode species with host size and host sex

\begin{tabular}{ccccc}
\hline \multirow{2}{*}{ Helminth species } & \multicolumn{2}{c}{ Host Size } & \multicolumn{2}{c}{ Host Sex } \\
\cline { 2 - 5 } & $P$ & $R^{2}$ & $P$ & $R^{2}$ \\
\hline Haematoloechus $\mathrm{sp}$. & 0.434 & - & 0.109 & - \\
\hline Diplodiscus $\mathrm{sp}$. & 0.020 & 0.45 & 0.449 & - \\
\hline Pleurogenoides sp. & 0.000 & 0.142 & 0.143 & - \\
\hline Glyphtelmins sp. & 0.000 & 0.155 & 0.311 & - \\
\hline
\end{tabular}

\section{Results}

\subsection{Trematode Fauna}

The trematode infection consisted of four species. The identification only reported to the genus level because of the inappropriate fixation. In the beginning, rice frogs caught by hand and directly injected and immersed by $96 \%$ alcohol. This treatment caused the specimens wrinkled and folded in which difficult to ensure to the species level. However, the genus character still recognized.

The specific group in which infected frog lungs belong to the genus Haematoloechus Looss, 1899. Haematoloechus sp. had an elongate body and vitellarium extends into the hind body. The trematode infection was also dominated by common species such as Pleurogenoides sp., Diplodiscus sp., and Glypthelmins 
sp. (Figure 1). Member of genus Pleurogenoides Travassos, 1921 predominantly found in intestine (Table 1). As same as the key [8], Pleurogenoides had a small and oval body; characterized by moderately long caeca, terminate near the anterior margin of testes with symmetrical testes and postcaecal.

The other intestinal flukes belonging to Glypthelmins sp. was characterized by an elongate body with spines extending from anterior end to varying level of the hind body. Oral sucker subterminal, larger than ventral sucker. Prepharynx short, and pharynx well developed. Caeca long extend to near posterior end of the body, but do not reach it. Testes are symmetrical and intercaecal. Genital pore median, in forebody. Ovary submedian, and anterior to testes. Lastly, Diplodiscus sp. mostly occurred on frogs' caecum with a conical body and characterized by a single testis and intercaecal. In addition, vitelline follicules are extending along caeca.

\subsection{Level of Infection}

Of the 120 frogs examined, 41 frogs were infected by trematodes, and 79 frogs were not infected. This showed that the prevalence of positively infected was $65.8 \%$. Haematoloechus sp. had the highest prevalence (35.8\%), while the Pleurogenoides sp. was the lowest (18.3\%). In contrast, Pleurogenoides sp. had the highest abundance (8.5) and Haematoloechus sp. had the lowest abundance (Table 2).

\subsection{The composition of trematode infection in each site of viscera}

Haematoloechus sp. only restricted on lung with $35.8 \%$ prevalence. Diplodiscus sp. infected two parts of viscera, i.e., intestine and caecum, wherein the highest prevalence was in the caecum (19.2\%). Pleurogenoides sp. and Glypthelmins sp. were found in three sites of viscera (stomach, intestine, and caecum), and both of them mostly found in the intestine (Table 1).

\subsection{Correlation between host body size and host sex with the number of parasites}

The observed frogs consist of 64 males and 56 females with varies between $15.8 \mathrm{~mm}$ and $69.3 \mathrm{~mm}$. Based on differences in host body size and host sex, there is a significant correlation between host body size and total infection of trematode $\left(\mathrm{R}^{2}=0.180, \mathrm{P}=0.00\right)$. On the contrary, the correlation between sex and parasite number was not significant $(\mathrm{P}=0.173)$.

There was no significant correlation found between all trematodes species and host sex (Table 3). Correlation of Haematoloechus sp. is not significant with host size $(\mathrm{P}=0.434)$, while the other three types are significant.

\section{Discussion}

All trematodes obtained in this research are common as anuran parasites. Anurans have an important role as hosts, both definitive and intermediate hosts, and also as paratenic hosts in the transmission of parasitic worms
[9]. The transmission related to the ecology and feeding behaviour of the host. According to Nurmainis [10], the groups of rice frog's diet in Bogor district consist of insect, crustacean, myriapod, arachnid, gastropod, small amphibian, and fish.

Our result showed the highest prevalence of trematodes reached by Haematoloechus sp. The species belong to Haematoloechus are known in every continent except Antarctica [11]. More than 50 species of this genus have been described around the world [12]. In Southeast Asia, Haematoloechus singaporensis recorded as a new species in Singapore [13]. Haematoloechus sp. also found in Shanghai with high prevalence, counted at $24.44 \%$ [14]. In general, the frog becomes infected with Haematoloechus spp. by ingested odonate as its intermediate host [15].

Diplodiscus sp. is part of the Family Diplodiscidae which is predominantly in amphibians but also found representative in reptile and fish [16]. The species of genus Diplodiscus may either infect tadpole and frog with a snail as its first intermediate host [17]. This statement explains how the small frog of this research ( $20.7 \mathrm{~mm}$ ) could be infected by Diplodiscus sp.

The highest infection rate and mean intensity were occupied by Pleurogenoides sp. (1-268). More than 26 valid species of genus Pleurogenoides from frogs have been reported around the world. The intermediate host of genus Pleurogenoides consist of gastropod, dragonflies, caddisflies, beetles, mayflies, alderflies, isopod, and amphipod crustacean [18]. The chance of ingesting those gastropods and aquatic insect mention above could explain the infection rate comes from.

The Genus Glypthelmins is the single genus of Family Glypthelminthidae and comprises 19 to 28 species worldwide which is parasitizing the intestine of amphibians [19-20]. Transmission of Glypthelmins transferred by consuming cysts that found in their own shed skin and develops to adults in the intestine [7, 21].

Our result shows a significant increase in helminth intensity related to host size. Consequently, the bigger size of the host is more parasitized. The large-body host provides more space of food ingested, more space of surface area [22]. Also, the larger host has a longer time to live, so they have the possibility to be exposed by parasites longer [23].

Regarding the relationship between parasite number and host-sex, there was no significant correlation. It is similar to the research of Comas et al. [24] which showed no significant patterns between host-sex and prevalence. On the other side, there were significant differences between the intensity of infection and sexes in Gonzales and Hamann [25]. They found that mean intensity of female frogs was higher than males. Indeed, the sex-linked patterns of infection is still unclear.

In the special case of this research, Haematoloechus sp. did not correlate to the host size while all the other three species had significant differences. The smallest frog infected with Haematoloechus sp. has a size of 22.8 $\mathrm{mm}$. It is relevant to Bolek and Janovy [26] which analyzed about small frogs infected with frog lung flukes. The mean of their northern leopard frogs was $30.85 \mathrm{~mm}$. Bolek and Janovy [26] indicates that the 
small frogs infected with frog lung flukes by nonodonate arthropods such as Coleoptera, Ephemeroptera, Hemiptera, and Amphopida. Those nonodonate arthropods infected with metacercariae located in the head, legs, and hemocoel.

\section{Conclusion}

To sum up, there were four species of trematodes infected rice frogs $F$. cancrivora, i.e. Haematoloechus sp., Diplodiscus sp., Pleurogenoides sp., and Glypthelmins sp. The transmission depends on the host ecology and feeding behaviour. It affects the calculation of prevalence, mean intensity, means abundance, and infection rate. This research also found that the infection related to the host size.

The author is grateful to Dra. Helen Kurniati, Wahyu Tri Laksono, and Syaripudin for their kindness giving their rice frog collection to be able to examine. Additionally, thanks to Dr. Kartika Dewi for her help in collecting the trematodes and her guidance to the author. The frog collection was funded by DIPA Project of Research Center for Biology LIPI in 2016 from subprogram CITES.

\section{References}

1. E. Suzanna, F. Satria, M.D. Kusrini, Marlefzena, Media Konservasi IX, (2004)

2. M. Astuti, Perbedaan Prevalensi Endoparasit pada Katak Sawah (Fejervarya cancrivora) dan Katak Lembu (Rana catesbeiana Shaw) (Skripsi: Universitas Negeri Semarang, Semarang, 2017)

3. M.P. Holland, D.K. Skelly, M. Kashgarian, S.R. Bolden, L.M. Harrison, M. Cappello, J. Zool., 271 (2006) DOI: $\underline{10.1111 / \mathrm{j} .1469-7998.2006 .00229 . \mathrm{x}}$

4. Djoko T. Iskandar, Amfibi Jawa dan Bali (Puslitbang Biologi-LIPI, Bogor, 1998)

5. M.D. Kusrini, R.A. Alford, Traffic Bulletin 21, 1 (2006)

6. H. Kurniati, E. Sulistyadi, Jurnal Biologi Indonesia 13, 1 (2017)

7. J. Koprivnikar, D.J. Marcogliese, J.R. Rohr, S.A. Orlofske, T.R. Raffel, P.T.J. Johnson, EcoHealth, 9 (2012) DOI: $10.1007 / \mathrm{s} 10393-012-0785-3$

8. R.A. Bray, D.I. Gibson, A. Jones, Keys to the Trematoda. Vol. 3 (CABI Publishing, Wallingford, 2008)
9. A.A. Imasuen, H.J. Ozemoka, M.S.O. Aisien, Int. J. Zool., 2012 (2012)

10. Nurmainis, Kebiasaan makanan kodok sawah Rana cancrivora di Kabupaten Bogor, Jawa Barat (Skripsi: Institut Pertanian Bogor, Bogor, 2000)

11. V. Leon-Regagnon, J. Topan, Zootaxa 4526, 3 (2018) DOI: $\underline{10.11646 / \text { zootaxa.4526.3.1 }}$

12. V. Leon-Regagnon, D.R. Brooks (2003). J. Parasitol. 89, 6 (2003) DOI: $10.1645 / G E-95 R$

13. P.H. Yuen, Three trematodes from Malayan Amphibian including two new species. J. Parasitol., 48 (1962) DOI: 10.2307/3274901

14. Q. Men, H. Han, Q. Zhao, W. Xia, H. Dong, S. Zhu, Z. Wang, C. Li, X. Zhu, B. Huang, Acta Parasitol. 61, 4 (2016) DOI: 10.1515/ap-2016-0111

15. M.G. Bolek, J. Janovy, J. Parasitol. 93, 3 (2007) DOI: $\underline{10.1645 / \mathrm{GE}-1011 \mathrm{R} .1}$

16. A. Jones, "Family Diplodiscidae Cohn, 1904." (2005). In: A. Jones, R.A. Bray, D.I. Gibson, (Eds.): Keys to the Trematoda, Volume 2 (CABI Publishing and The Natural History Museum, London, 2005)

17. E.C. Herber, J. Parasitol. 25, 3 (1939) DOI: $10.2307 / 3272502$

18. I.V. Chikhlyaev, A.B. Ruchin, A.I. Fayzulin, Nusantara Biosci 10, 4 (2018) DOI: $10.13057 /$ nusbiosci/n100410

19. U.J. Razo-Mendivil, V. Leon-Regagnon, G. PerezPonce de Leon, Org. Divers. Evol., 6 (2006) DOI: $10.1016 /$ j.ode.2005.12.005

20. J. Miquel, S. Poonlaphdecha, A. Ribas, Tissue and Cell, 54 (2018) DOI: 10.1016/j.tice.2018.08.013

21. G.W. Martin, J. Parasitol. 55, 4 (1969) DOI: $10.2307 / 3277209$.

22. R. Poulin, Annu. Rev. Ecol. Evol. Syst. 28, 1 (1997) https://doi.org/10.1146/annurev.ecolsys.28.1.341

23. R. Poulin, Parasitology, 134 (2007) DOI: 10.1017/S0031182006002150

24. M. Comas, A. Ribas, C. Milazzo, E. Sperone, E. Tripepi, Acta Herpetol. 9, 1 (2014) DOI: $10.13128 /$ Acta_Herpetol-13117

25. C.E. Gonzales, M.I. Hamann, Parasitol. Res., 111 (2012) DOI: $\underline{10.1007 / \mathrm{s} 00436-012-3034-3}$

26. M.G. Bolek, J. Janovy, J. Parasitol. 93, 2 (2007) DOI: $\underline{10.1645 / \mathrm{GE}-1010 \mathrm{R} .1}$ 